\title{
Estimating Perfluorocarbon Emission Factors for Industrial Rare Earth Metal Electrolysis
}

\begin{abstract}
:
Rare earth (RE) metals have been widely applied in new materials, leading to their drastic production increase in the last three decades. In the production process featured by the molten-fluoride electrolysis technology, perfluorocarbon (PFC) emissions are significant and therefore deserve full accounting in greenhouse gas (GHG) emission inventories. Yet, in the '2006 IPCC Guidelines for National Greenhouse Gas Inventories', no method currently exists to account for PFC emissions from rare earth metal production. This research aims to determine emission factors for industrial rare earth metals production through on-site monitoring and lab analysis of PFC concentrations in the exhaust gases from rare earth metal electrolysis. Continuous FTIR measurements and time-integrated samples (analysed off-site by high-precision Medusa GC-MS) were conducted over 24-60 hour periods from three rare earth companies in China, covering production of multiple rare earth metals/alloys including Pr-Nd, La and Dy-Fe. The study confirmed that PFC emissions are generated during electrolysis, typically in the form of $\mathrm{CF}_{4}(\sim 90 \%$ wt of detected PFCs), $\mathrm{C}_{2} \mathrm{~F}_{6}(\sim 10 \%)$ and $\mathrm{C}_{3} \mathrm{~F}_{8}(<1 \%)$; trace levels of $\mathrm{c}_{-} \mathrm{C}_{4} \mathrm{~F}_{8}$ and $\mathrm{C}_{4} \mathrm{~F}_{10}$ were also detected. In general, PFC emission factors vary with rare earth metal produced and from one facility to another, ranging from 26.66 to $109.43 \mathrm{~g} / \mathrm{t}-\mathrm{RE}$ for $\mathrm{CF}_{4}$ emissions, 0.26 to $10.95 \mathrm{~g} / \mathrm{t}-\mathrm{RE}$ for $\mathrm{C}_{2} \mathrm{~F}_{6}$, and 0.03 to $0.27 \mathrm{~g} / \mathrm{t}-\mathrm{RE}$ for $\mathrm{C}_{3} \mathrm{~F}_{8}$. Converted to 211.60 to $847.41 \mathrm{~kg} \mathrm{CO}_{2}$-e/t-RE for total PFCs, this emissions intensity for rare earths electrolysis is of lower (for most RE production) or similar (Dy-Fe production) level of magnitude to industrial aluminium electrolysis.
\end{abstract}

Keywords: PFC, greenhouse gas, emission factor, rare earth metal, electrolysis

\section{Introduction}

\subsection{Rare Earth Metals Production \& PFC Greenhouse Gas Emissions}

'Rare earth metals' typically refer to a set of chemical elements in the periodic table, i.e. the fifteen lanthanides as well as scandium and yttrium. Rare earth (RE) metals have significant applications in new materials which are in wide demand in emerging and advanced industries such as permanent magnets and high-performance electronic devices. Therefore, in the last three decades, production of rare earth metals has soared dramatically. For instance, the global annual production of $\mathrm{Nd}_{2} \mathrm{Fe}_{14} \mathrm{~B}$ permanent magnets have increased from around 1 tonne in the $1980 \mathrm{~s}$ to more than 50,000 tonnes in around 2000 (Liu, 2008).

Since the 1990s, rare earth electrolysis using the molten fluoride-salt system has become the dominant production technology for rare earth metals. This replaced the molten chloride-salt system that was prevalent prior to the 1990s but suffered from several limitations, including: low 
current efficiency, generation of chlorine gas as an environmental pollutant, poor metal quality / purity and other reasons.

The fluoride-based molten salts electrolysis process used today for rare earths production shares many similarities to the process used by the primary aluminium industry. As with aluminium electrolysis, the fluoride electrolysis route for rare earths production has the potential to form perfluorocarbon (PFC) gases, including tetrafluoromethane $\left(\mathrm{CF}_{4}, \mathrm{PFC}-14\right)$ and hexafluoroethane $\left(\mathrm{C}_{2} \mathrm{~F}_{6}, \mathrm{PFC}-116\right)$, both of which are potent greenhouse gases; octafluoropropane $\left(\mathrm{C}_{3} \mathrm{~F}_{8}\right.$, PFC-218) is also occasionally reported in aluminium. According to the Intergovernmental Panel for Climate Change (IPCC)'s Fifth Assessment Report (2013), $\mathrm{CF}_{4}$ has an extremely long atmospheric lifetime of 50,000 years and a global warming potential (GWP100) of 6,630 compared to $\mathrm{CO}_{2}$ over 100 years, $\mathrm{C}_{2} \mathrm{~F}_{6}$ has a lifetime of 10,000 years and a GWP100 of 11,100 , and $\mathrm{C}_{3} \mathrm{~F}_{8}$ has a lifetime of 2,600 years and a GWP100 of 8,900 .

While global production of rare earth metals by molten electrolysis technology is still very low compared to global aluminium production (roughly $0.1 \%$ of aluminium in 2013, based on global output of rare-earth oxides versus metallurgical-grade aluminium oxide (US Geological Survey 2014; IAI 2014)), it is possible that the resulting volume of greenhouse gas emissions can be comparatively large. Taking neodymium $(\mathrm{Nd})$ metal production by $\mathrm{Nd}$ oxide electrolysis for example, it has been estimated by Vogel et al. (2017a) that in a worst-case scenario, the off-gases from the process could contain as much as $7 \% \mathrm{CF}_{4}$ and $0.7 \% \mathrm{C}_{2} \mathrm{~F}_{6}$. When considering the extremely large GWPs of these PFC gases and global production of roughly 30,000 t/year Nd

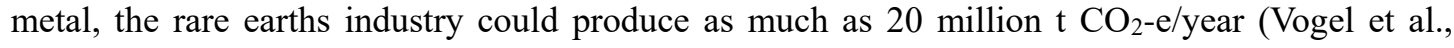
2017a).

If a significant volume of PFC generation from the rare earths industry was confirmed, this would go towards explaining the large discrepancy or 'gap' that has been found between (i) global atmospheric measurements of PFC emissions (a 'top-down' approach for accounting PFCs) and (ii) global 'bottom-up' accounting of PFC emissions from aluminium and semi-conductor industries. Both these industries are currently considered the only major anthropogenic sources of PFCs, with both employing methodologies from the IPCC to account for PFC emissions. Using atmospheric data, $\mathrm{Kim}$ et al. (2014) showed that as much as $50 \%$ of $\mathrm{CF}_{4}$ and $48 \%$ of $\mathrm{C}_{2} \mathrm{~F}_{6}$ emissions over the

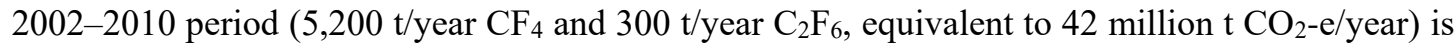
being under-estimated or unaccounted for from global industrial sectors.

The potential for large volumes of PFC gas emissions (combined with extremely high GWPs) from the rare earth metal industry implies that it should not be overlooked in terms of mitigating global warming. Therefore, evaluation and calculation of the global warming contribution from the rare earth metal industry is urgently needed. However, in the 2006 IPCC Guidelines for National Greenhouse Gas Inventories (henceforth abbreviated to 2006 IPCC Guidelines), no guideline exists for the rare earth metal industry. One factor might have been the low proportion of Chinese contributors to the 2006 IPCC Guidelines (only 3.6\% of authors and review editors for the entire 2006 IPCC Guidelines and only 1.1\% for Volume 3 of the 2006 IPCC Guidelines: 'Industrial Processes \& Product Use' (IPPU), where metal industry emissions are described) despite the fact that about $90 \%$ of rare earth metals globally are produced in China. Another more likely reason is that the global metal production of rare earths prior to 2006 was too small to consider as a significant contributor to GHG emissions, as already discussed above.

A further critical factor is the fact that to date there is a lack of quality academic research to 
support a robust guideline for rare earth metal industry, if such a guideline were to be proposed. By contrast, there are numerous academic works and industrial studies on PFC emissions from primary aluminium production (Tabereaux, 1994; Rhoderick et al., 2001; Chase et al., 2005; Zhao et al., 2008; Wong et al., 2015). These have built up a robust foundation for the description of a detailed method for estimating PFC emissions from aluminium production in the 2006 IPCC Guidelines.

As a response to the above, recently a few studies on PFC emissions from the rare earth metals industry have been published. An example is the research conducted by Vogel et al. (2017a) who studied the electrochemistry of the neodymium oxide electrolytic system and the resulting anodic gas emissions. As the goal was to reduce PFC emissions, the paper focused on the interaction mechanism between $\mathrm{CO} / \mathrm{CO}_{2}$ and $\mathrm{CF}_{4}$ emission concentrations and voltage across the electrochemical cell. With this groundwork, Vogel and Friedrich (2017b) continued the research and concluded that poor control of oxide concentrations of the electrolyte can cause higher PFC emissions. Therefore, a process control strategy similar to that in aluminium electrolysis was proposed to reduce PFCs, with continuous and precise oxide feeding being essential elements.

Vogel and his colleagues' research was conducted under laboratory conditions but mimicked industrial production. Given the variation of production engineering and gas scrubbing, this approach is effective in exploring the fundamental mechanisms of PFC emission but cannot be applied to estimating actual PFC emissions from the rare earth metal production industry. Therefore, Zhang et al. (2018) conducted research which measured continuous PFC emissions in an actual rare earth metal production facility. Zhang's work only focused on the PFC emission from production of $\mathrm{Nd}$ metal and Dy-Fe alloy at one rare earth production company. However, there are currently more than ten types of rare earth metals and alloys being produced by electrolysis every year. These include (in order of production output, from greatest to smallest): Pr-Nd, Nd, La, Dy-Fe, Ga-Fe, Ho-Fe, Pr, Ce, La-Ce and Y-Mg (ranking based on production data from major producers, covering $95 \%$ of the market). Furthermore, Zhang's data is limited in that it focused only on $\mathrm{CF}_{4}$ emissions and did not measure other important $\mathrm{PFC}$ gases such as $\mathrm{C}_{2} \mathrm{~F}_{6}$ and $\mathrm{C}_{3} \mathrm{~F}_{8}$. Uncertainty analyses were also not provided from the study. Since the time of Zhang's measurements in 2014, there have also been significant improvements made in rare earth electrolysis technologies and in the operations of the process, which are expected to help reduce PFC emissions. Recently, for cleaner production, gas-collection hoods for each electrolytic cell have been applied in some newly established production shops. There was no estimation of gas collection efficiencies of the hooding systems (i.e. emission factors did not take into account any fugitive emissions) in Zhang's (2018) study, which is a further significant uncertainty in this previous work.

\subsection{Aims of this Work}

In light of the limitations of prior studies and the new developments in rare earth metal production, this paper goes further to measure PFC emissions from the production of Pr-Nd alloy, Dy-Fe alloy and La metal from different electrolytic cell sizes and gas exhaust systems. It aims to provide greater coverage of PFC emissions in the rare earth metal industry so that PFC emission factors for different rare earth metals produced with different technologies can be proposed. The measurement of the PFC emissions was conducted in three typical rare earth companies in 
Ganzhou, Jiangxi province. These three companies consist of diversified technologies including old and new production shop settings, small and large electrolytic cells, and low and high cell current technologies.

\subsection{The Fluoride Electrolysis Process for Rare Earth Metal Production}

The dominant technology worldwide for primary production of RE metals and alloys is using molten fluoride-salt electrolytic reduction, similar to primary aluminum's Hall-Héroult process. The raw materials for rare earths metal production are in the form of rare earth oxides (REO). In general, REOs are dissolved and electrolytically reduced in a molten salt of rare earth fluorides $\left(\mathrm{REF}_{\mathrm{s}}\right)$ and lithium fluoride $(\mathrm{LiF})$, with graphite anodes and inert or consumable cathodes. The temperature in the reaction cell is high $\left(\sim 1000-1100{ }^{\circ} \mathrm{C}\right)$ and can vary depending on technology or metal produced, and be periodically interrupted or disturbed by anode replacements, cathode removal/replacement and removal of liquid RE metal/alloy.

Industrial fluoride-based rare earth smelters can be arbitrarily categorised into three classes by electrical current (and therefore the size of electrolysis cells), namely: low amperage (LA) technology, high amperage (HA) technology and high amperage with automatic control (HAA) technology. Low amperage technology (LA) are those with electrical current lower than $10 \mathrm{kA}$ and typically employ small round-shaped cells, with only single (or several) vertical anodes and cathodes, and with very low levels of automation. For high amperage technology (HA and HAA), the current is higher than $10 \mathrm{kA}$. Typically, these use round or rectangular shaped cells, equipped with multiple vertical anodes and/or cathodes (Wen et al., 2012; Vogel \& Friedrich, 2015). Some high amperage technologies may be equipped with 'Automatic Process Control' features (HAA), being able to automate rare earth oxide feeding so as to ensure continuous metal production and detection of anode effects that generate PFC.

PFC emissions are mainly in the form of $\mathrm{CF}_{4}$ and $\mathrm{C}_{2} \mathrm{~F}_{6}$ and are often associated with 'anode effects' (AEs), resulting in passivation of graphite anodes (loss of electrical current-carrying capacity) and high cell voltage. These PFC emissions may be produced in the following manner (taking $\mathrm{Nd}$ metal electrolysis as an example) (equations 1-4):

$$
\begin{aligned}
& 4 \mathrm{NdF}_{3}+3 \mathrm{C} \rightarrow 4 \mathrm{Nd}+3 \mathrm{CF}_{4} \\
& 4 \mathrm{LiF}+\mathrm{C} \rightarrow 4 \mathrm{Li}+\mathrm{CF}_{4} \\
& 2 \mathrm{NdF}_{3}+2 \mathrm{C} \rightarrow 2 \mathrm{Nd}+\mathrm{C}_{2} \mathrm{~F}_{6} \\
& 6 \mathrm{LiF}+2 \mathrm{C} \rightarrow 6 \mathrm{Li}+\mathrm{C}_{2} \mathrm{~F}_{6}
\end{aligned}
$$

In addition to being directly formed by electrolysis (equations 1-4), PFCs can also be generated by first forming $\mathrm{COF}_{2}$ or $\mathrm{COF}$ electrochemically at lower electrode potentials (equations 5-6), which are unstable and will spontaneously react with $\mathrm{C}$ to form $\mathrm{CF}_{4}$ and $\mathrm{CO}$ (equations 7-8) as follows (Vogel 2017a, Kjos 2018):

$$
\begin{aligned}
& \mathrm{Nd}_{2} \mathrm{O}_{3}+2 \mathrm{NdF}_{3}+3 \mathrm{C} \rightarrow 4 \mathrm{Nd}+3 \mathrm{COF}_{2} \\
& \mathrm{Nd}_{2} \mathrm{O}_{3}+\mathrm{NdF}_{3}+3 \mathrm{C} \rightarrow 3 \mathrm{Nd}+3 \mathrm{COF} \\
& 2 \mathrm{COF}_{2}+\mathrm{C} \rightarrow \mathrm{CF}_{4}+2 \mathrm{CO} \\
& 4 \mathrm{COF}+\mathrm{C} \rightarrow \mathrm{CF}_{4}+4 \mathrm{CO}
\end{aligned}
$$




\section{Methodology}

Two simultaneous methods were used for sampling PFC emissions: (i) continuous onsite monitoring with an FTIR and (ii) time-integrated sampling (collection of emissions into gas canisters) with offsite lab analysis. In this study we focused on estimating emission factors for $\mathrm{CF}_{4}$, $\mathrm{C}_{2} \mathrm{~F}_{6}$ and $\mathrm{C}_{3} \mathrm{~F}_{8}$.

The most commonly applied equipment for monitoring PFC emissions is the Fourier Transform Infrared (FTIR) spectrometer. In theory, it is capable of capturing the emission data of all PFCs continuously in real-time. However, in RE metal production, in addition to emissions of major PFC gases $\left(\mathrm{CF}_{4}\right)$, there are minor PFCs including $\mathrm{C}_{2} \mathrm{~F}_{6}$ and $\mathrm{C}_{3} \mathrm{~F}_{8}$ which can be more difficult to detect with the FTIR. It must be noted that when measuring these emissions with the FTIR, gases will only be detected when emission concentrations exceed certain detection limits, an issue related to the reference spectrum used in the FTIR database. Therefore during gas measurements, it is crucial to record information relating to the configuration of the production system and ensure that the on-site gas monitoring point has sufficiently high emission concentrations. In this study, $\mathrm{CF}_{4}$ emissions were primarily estimated using FTIR measurements, whereas $\mathrm{C}_{2} \mathrm{~F}_{6}$ and $\mathrm{C}_{3} \mathrm{~F}_{8}$ emissions were estimated using the time-integrated sampling and lab analysis technique.

As emissions from a single cell can differ from other cells due to variations in structure, operating conditions and production stage, it is better to monitor emissions from a group of cells, e.g. 12 cells or more, even up to one 'potroom' or 'potline' of cells (a chain of cells connected in series to the same electrical circuit and same exhaust gas system) so as to reduce inherent measurement error. However, the number of cells covered must be balanced by maintaining sufficiently high concentrations of $\mathrm{CF}_{4}, \mathrm{C}_{2} \mathrm{~F}_{6}$ and $\mathrm{C}_{3} \mathrm{~F}_{8}$ that can still be accurately measured with the FTIR and time-integrated sampling. An optimum location can be in a common gas exhaust duct from a group of cells or from the gas stack before/after gas treatment for the entire potline.

Another issue that must be considered is the gas collection efficiency. During the monitoring process, the percentage of gases that is fully captured by the gas collection systems against all gases generated by the cells must be estimated. If gas collection efficiency is lower than $90 \%$ (i.e. more than $10 \%$ fugitive or uncontrolled emissions is not collected by the gas suction system), then there should be extra measurements of fugitive emissions at the exit point of the potroom/production shop where electrolysis cells are located, e.g. if there is a natural flow of air to the roof (Fraser et al., 2013). However, since the three rare earth companies monitored did not have any readily identifiable / accessible roof vents, gas collection efficiency was estimated at each company by releasing known quantities of $\mathrm{SF}_{6}$ gas at the cell and using this as a tracer.

The amount of gas emissions in RE metal production can change over time. This may result from a variety of major process events on the cells, such as anode/cathode changes, metal removal, voltage/current change, RE oxide additions and the triggered 'anode effect' events. Therefore, to capture a representative period of operations/events, continuous measurements should ideally be conducted over a minimum of 24 hours (generally, the longer the time frame the better). During monitoring, all major process events were recorded so that any features in the gas concentrations can be correlated with these events - note that these features are not the focus of this paper and therefore are not elaborated further in this work. Furthermore, production data (metal and quantity produced) and technology factors (line current and cell size, which can fundamentally change the 
emission outcomes) were also recorded.

For this research, three companies located in Ganzhou, Jiangxi province of China were selected as the representative cases: Qiandong Rare Earths Group Co. Ltd (Qiandong in abbreviation), National Engineering Research Center for Ionic Rare Earth (Ionic Rare Earth Center in abbreviation) and Jiangxi South Rare Earth High Tech. Co. Ltd (Jiangxi South in abbreviation). Qiandong specialises in three widely used RE metals including Pr-Nd alloy, La and Dy-Fe alloy. In contrast, Ionic Rare Earth Center attaches more importance on research, especially on new technologies for RE metals processing from ionic rare earths. Thus, measurement data from the Ionic Rare Earth Center can provide additional new information to the PFC emission spectrum. Jiangxi South was also included in the study as it employs some of the larger high-amperage ( $>10 \mathrm{kA})$ cell technologies.

In 2016, approximately half of China's RE metals are produced by companies/institutions in Ganzhou, and Qiandong accounts for more than 1/3 of the total production in Ganzhou. In light of the above, the three companies participating in this study can be a valid representation of PFC emissions in the RE metal production industries in China, or even in the world.

\subsection{Continuous On-Site FTIR Monitoring}

For on-site monitoring of the $\mathrm{CF}_{4}$ emission, an FTIR spectroscopy instrument (MKS MultiGas $^{\mathrm{TM}} 2030$ or MG2030, which is competent in capture of $\mathrm{CF}_{4}$ emissions) was employed. Where possible, we measured emissions from a series/group of pots so as to ensure data was representative and to minimise the risk of major inaccuracies that are more likely to occur in measuring single pots (Table 1). Figure 1 shows the schematic diagram of the intended sampling set up and process.

Table 1: Intended sampling arrangement for monitoring PFC emissions at the three RE companies

\begin{tabular}{cccccc}
\hline Company & & Qiandong & Ionic Rare & Earth Center & Jiangxi South \\
\hline $\begin{array}{c}\text { Potline } \\
\text { (metal produced) }\end{array}$ & $P r-N d$ & $D y-F e$ & $L a$ & $P r-N d$ & $P r-N d$ \\
No. of cells/pots & 15 & 1 & 6 & 6 & 2 \\
Line current (kA) & 5 & 5 & 5 & 6 & 11 \\
Time frame (hours) & 60 & 24 & 36 & 36 & 24 \\
Monitoring equipment & $\begin{array}{l}M K S \\
\text { collected in sampling canisters for offsite lab analysis }\end{array}$ \\
\hline
\end{tabular}

As explained previously, in addition to $\mathrm{CF}_{4}$ there are minor $\mathrm{PFC}$ gas emissions including $\mathrm{C}_{2} \mathrm{~F}_{6}$ and $\mathrm{C}_{3} \mathrm{~F}_{8}$ which cannot be easily detected by $M K S M G 2030$. However, it is still important to estimate emission factors for these two critical PFC gases. To circumvent this issue, we also collected 'time-integrated' gas emission samples (simultaneously with FTIR measurements over the same sampling durations) and stored them in canisters for subsequent offsite lab analysis (Figure 1); offline analyses provided considerably lower detection limits for other C-F gases. 
Through this approach, we estimate ratios of emission volumes for all other PFC components compared to $\mathrm{CF}_{4}$, whereby emission factors for $\mathrm{C}_{2} \mathrm{~F}_{6}$ and $\mathrm{C}_{3} \mathrm{~F}_{8}$ can be calculated once $\mathrm{CF}_{4}$ emission factors are known/confirmed - details are explained in section 2.4.

In this research, the emission factor of $\mathrm{CF}_{4}\left(\mathrm{EF}_{\mathrm{CF} 4}\right)$ is calculated directly by the equation below:

$$
E F_{C F 4}=\frac{\left[C F_{4}\right] \times t \times F \times 0.088}{22.4 \times 10^{6} \times E c o l \times Q}
$$

Where $\left[\mathrm{CF}_{4}\right]$ is volume concentration (ppmv), using data from the FTIR; $t$ is total sampling time $(h) ; F$ is the average gas flow rate at the sampling point $\left(\mathrm{Nm}^{3} / \mathrm{h}\right) ; E c o l$ is gas collection efficiency and $Q$ is rare earth metal produced (tonnes) over the sampling time.

It was foreseeable during initial inspections that emissions from electrolysis cells could not be completely gathered and sent by gas collection systems to the exhaust gas stack, where sampling and measurements would be set up (Figure 1). Thus, a $\mathrm{SF}_{6}$ tracer gas was employed to estimate the gas collection efficiency at each company. Once this is known, the volumes of all gas emissions can be calculated and accurate and reliable emission factors can then be estimated.

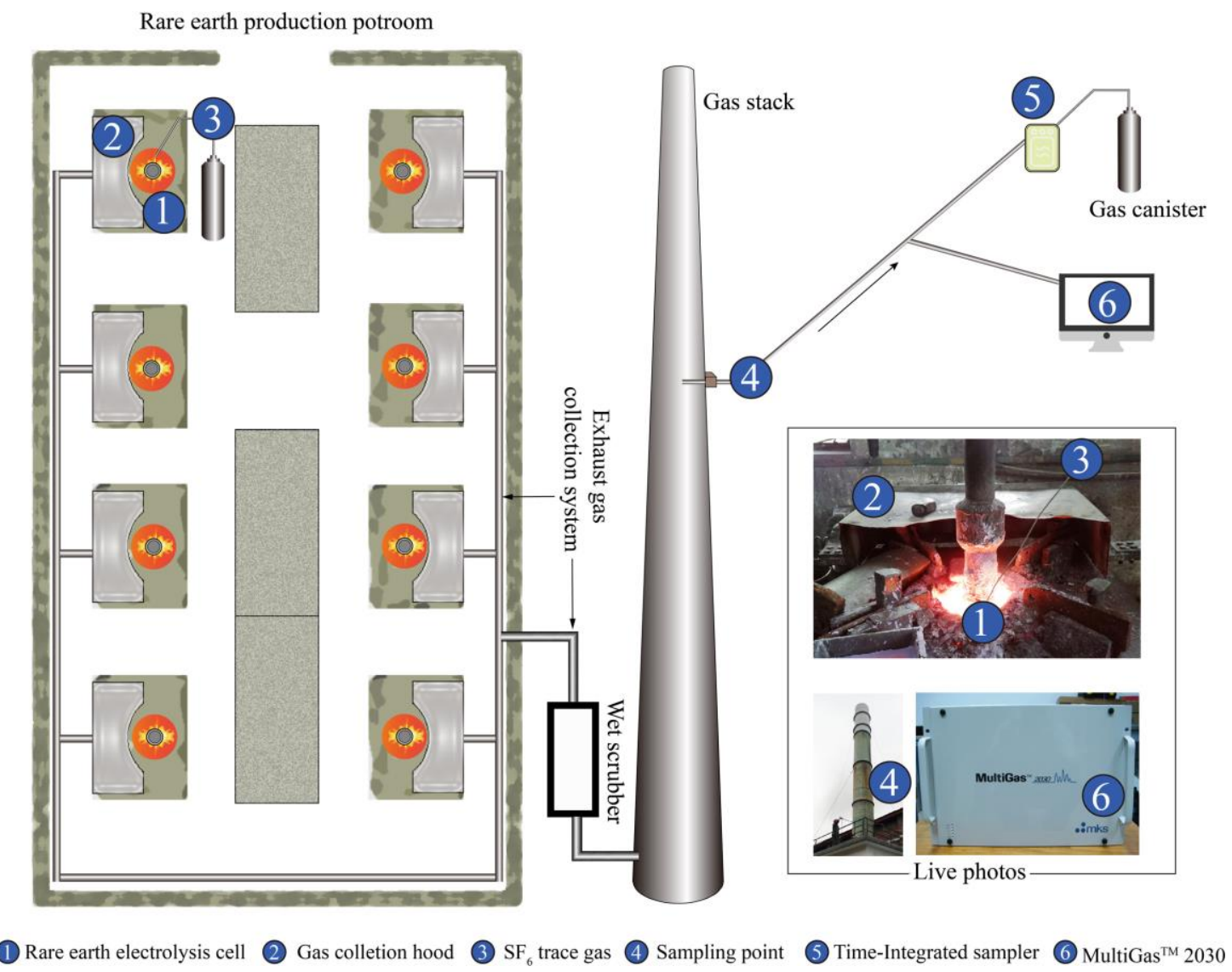

Figure 1: The arrangement for on-site monitoring and sampling of PFCs from a potroom of rare earth electrolysis cells.

\subsection{Time-Integrated Sampling and Lab Analysis}

Exhaust air was drawn from the exhaust gas stack by pump (M121-FP-BA1-L) through a sampling tube (1/4" OD Synflex tubing, Eaton, USA) at flow rate of $5 \mathrm{~L} / \mathrm{min}$ to feed both the 
in-situ FTIR system and time-integrated sampler. The sampler pressurized into pre-vacuumed 3-L stainless steel canisters (X23-2N, LabCommerce, Inc, USA) by means of a membrane pump (KNF-022, KNF Neuberger, Germany). The integrated flow was constrained by a mass flow controller (GFC17, AALBORG, USA) at a constant flow rate for each integrated sample. The flow rate ranged from $2.5 \mathrm{~mL} / \mathrm{min}$ to $3.5 \mathrm{~mL} / \mathrm{min}$ depending on the required integrated time of different samples.

Canister samples were transported to Beijing and analysed with a custom-built 'Medusa' gas chromatographic system with mass spectrometric detection (Agilent 6890/5975B, USA) for fluorinated greenhouse gases within one month. The system uses the technique developed by the Advanced Global Atmospheric Gases Experiment (AGAGE) and was operated in the lab of the Meteorological Observation Centre of the China Meteorological Administration (MOC/CMA). The measurements are linked to AGAGE standard scales (Prinn et al., 2018) and the precisions are $<0.5 \%$ for $\mathrm{CF}_{4}, \mathrm{C}_{2} \mathrm{~F}_{6}, \mathrm{C}_{3} \mathrm{~F}_{8}, \mathrm{c}_{-} \mathrm{C}_{4} \mathrm{~F}_{8}$ and $\mathrm{C}_{4} \mathrm{~F}_{10}$. The detailed analysis method was described by Zhang et al. (2018). For the samples with pressure less than $10 \mathrm{psi}$, a dilution procedure was used to pressurize the sample by zero gas to ensure there is enough volume.

\subsection{Methodology for Estimating Gas Collection Efficiency using SF 6}

\section{Tracer}

As illustrated in Figure 1, high concentration $\mathrm{SF}_{6}(0.498 \%$, Beijing Beifenhaipu Gas Industrial, China) was released at a constant flow rate by a mass flow controller (20 to 1000 $\mathrm{mL} / \mathrm{min}$ depending on the releasing time period) at a chosen cell at each RE potroom. The end of the gas release tubing was placed as close to the anode as possible (generally less than $1 \mathrm{~cm}$ away from anodes). Actual gas release periods (i.e. monitoring period) and flow rates at each potroom are listed in Table 2.

$\mathrm{SF}_{6}$ was diluted in the exhaust gas collection system and later collected into stainless steel canisters together with other greenhouse gases in the exhaust gas. The $\mathrm{SF}_{6}$ concentration was analyzed by the Medusa-GC/MS in MOC/CMA lab (described in section 2.2) with an uncertainty of $0.5 \%$. Thus, the gas collection efficiency was calculated as follows:

$$
\mathrm{E}_{\mathrm{col}}=\frac{\mathrm{C}_{\text {canister }} \times \mathrm{F}_{\text {exhaust }}}{\mathrm{C}_{\text {standard }} \times \mathrm{F}_{\text {standard }}} \quad \text { (Eq. 10); }
$$

Here $E_{c o l}$ is gas exhaust collection efficiency, $C_{\text {canister }}$ and $C_{\text {standard }}$ are $\mathrm{SF}_{6}$ concentrations of canister samples and of the $\mathrm{SF}_{6}$ tracer standard, respectively, while $F_{\text {exhaust }}$ and $F_{\text {standard }}$ are the flow rates of the exhaust gas and the released flow rate of $\mathrm{SF}_{6}$ tracer gas (high concentration standard), respectively. Here $C_{\text {standard }}$ is $0.489 \%$.

\subsection{Estimating Emission Factors of $\mathrm{C}_{2} \mathrm{~F}_{6}$ and $\mathrm{C}_{3} \mathrm{~F}_{8}$}

The MKS MG2030 FTIR is capable of measuring the emission of $\mathrm{CF}_{4}$ from production lines, yet it is unable to detect the gas emissions such as $\mathrm{C}_{2} \mathrm{~F}_{6}$ and $\mathrm{C}_{3} \mathrm{~F}_{8}$ directly, due to limitations of the reference spectrum used in the FTIR. To estimate emission factors for these two gases, we calculate their emission volumes by referring to the emission volume ratios (which is measured in 
the lab from time-integrated samples) between them and $\mathrm{CF}_{4}$.

The emission factors $(E F)$ of $\mathrm{C}_{2} \mathrm{~F}_{6}$ and $\mathrm{C}_{3} \mathrm{~F}_{8}$ can be calculated by the expressions as below:

$$
\begin{aligned}
& E F_{C 2 F 6}=E F_{C F 4} \times(138 / 88) \times\left(D_{C 2 F 6} / D_{C F 4}\right) \\
& E F_{C 3 F 8}=E F_{C F 4} \times(188 / 88) \times\left(D_{C 3 F 8} / D_{C F 4}\right)
\end{aligned}
$$

Where, $D_{C F 4}, D_{C 2 F 6}$ and $D_{C 3 F 8}$ are the average concentration of $\mathrm{CF}_{4}, \mathrm{C}_{2} \mathrm{~F}_{6}$ and $\mathrm{C}_{3} \mathrm{~F}_{8}$ measured in the lab from time-integrated sampling canisters are respectively, and $E F_{C F 4}$ is the estimated emission factor of $\mathrm{CF}_{4}$ (measured simultaneously by FTIR on the same potline).

\section{Results and Discussion}

\subsection{Estimated $\mathrm{CF}_{4}$ Emission Factors from On-Site FTIR Monitoring}

The first FTIR time series data of $\mathrm{CF}_{4}$ emissions covered 15 pots from the $\mathrm{Pr}-\mathrm{Nd}$ production potline in Qiandong, over 60 hours of monitoring. As shown in Figure 2, a number of anode effect events, represented by the sharp peaks in $\mathrm{CF}_{4}$ emissions, were identified. The maximum observed $\mathrm{CF}_{4}$ concentration was $0.610 \mathrm{ppm}$. It was estimated that $75 \%$ of $\mathrm{CF}_{4}$ emissions were related to peak or anode effect (AE) emissions, with $25 \%$ attributed to 'non-anode effect' (NAE) emissions, as determined by integrating the emission time series for peak vs. non-peak emission periods. Based upon this data, a $\mathrm{CF}_{4}$ emission factor of $26.66 \mathrm{~g} / \mathrm{t}-\mathrm{RE}$ was calculated, with a corresponding $\mathrm{CO}_{2}$ equivalent emission factor of $176.76 \mathrm{~kg} \mathrm{CO}_{2}$-e/t-RE. This is roughly $40 \%$ lower than the $307.65 \mathrm{~kg} \mathrm{CO}_{2}$-e/t-RE emission factor measured in 2014 for $\mathrm{Nd}$ production (Zhang et al., 2018, with emission values converted assuming the same $57.97 \%$ gas collection efficiency). This reduction in PFC emissions coincides with the installation of an automated feeding system for the rare earth oxides into the production line over the past 3 years. Therefore, this indicates that improvements to the electrolytic process and operations can reduce PFC emissions.

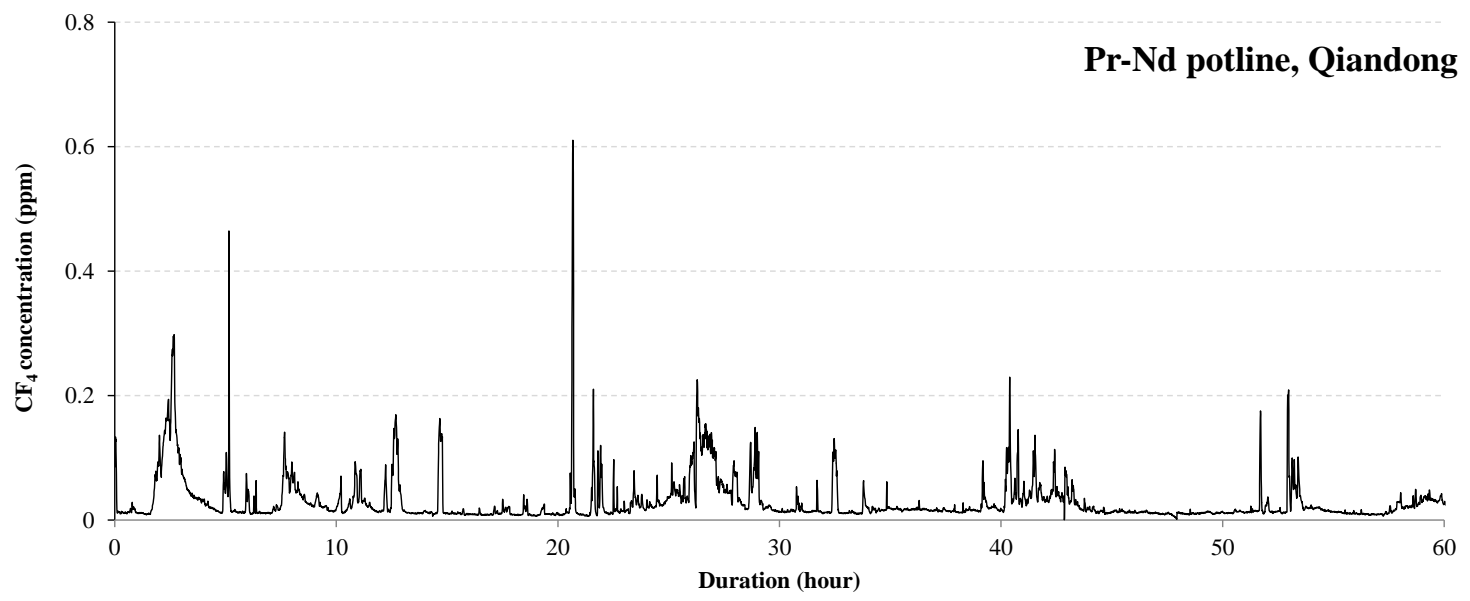

Figure 2: $\mathrm{CF}_{4}$ concentration of Pr-Nd potline (15 cells) in Qiandong during regular production 
emission factor for Dy-Fe production, exhaust gases from the cell was monitored over 24 hours (Figure 3). A series of anode effects (emission peaks) were observed with $3.029 \mathrm{ppm}$ as the maximum concentration of $\mathrm{CF}_{4}$. Many peak values relating to anode effects were greater than 0.5 ppm; an estimated $91 \%$ of $\mathrm{CF}_{4}$ emissions were related to these AEs, with $9 \%$ related to NAE emissions. The overall $\mathrm{CF}_{4}$ emission factor for Dy-Fe was $109.43 \mathrm{~g} / \mathrm{t}-\mathrm{RE}$, being equal to 725.52 $\mathrm{kg} \mathrm{CO}_{2}$-e/t-RE. In 2014, the $\mathrm{CO}_{2}$-equivalent emission factor in this same potline was $1,212.32 \mathrm{~kg}$ $\mathrm{CO}_{2}$-e/t-RE (Zhang et al. 2018, values converted with a $57.97 \%$ gas collection efficiency). We can see that the PFC emission had decreased significantly ( $40 \%)$, which again resulted from improvements to the electrolytic process and material feeding system.

Compared with the other three potlines, the $\mathrm{CF}_{4}$ emission factor for Dy-Fe production is the highest. One possible explanation is that the voltage for Dy-Fe electrolysis (at $12 \mathrm{~V}$ ) is much higher than in other potlines (e.g. $4 \mathrm{~V}$ higher than for the Pr-Nd potline). Operating at higher voltage makes it more likely to trigger anode effects which will produce more PFC gases. Another observation that supports higher PFC emissions is the fact that significantly more fluoride electrolyte is consumed in this Dy-Fe potline, with a two-fold greater fluoride consumption than Pr-Nd production. This is because more anode effects happened in this potline (Figure 3) which led to more PFC emissions. Finally, it should be stressed that there is a level of uncertainty in these results given that Dy-Fe sampling was conducted from only one cell, instead of multiple cells as discussed previously.

Dy-Fe potline, Qiandong

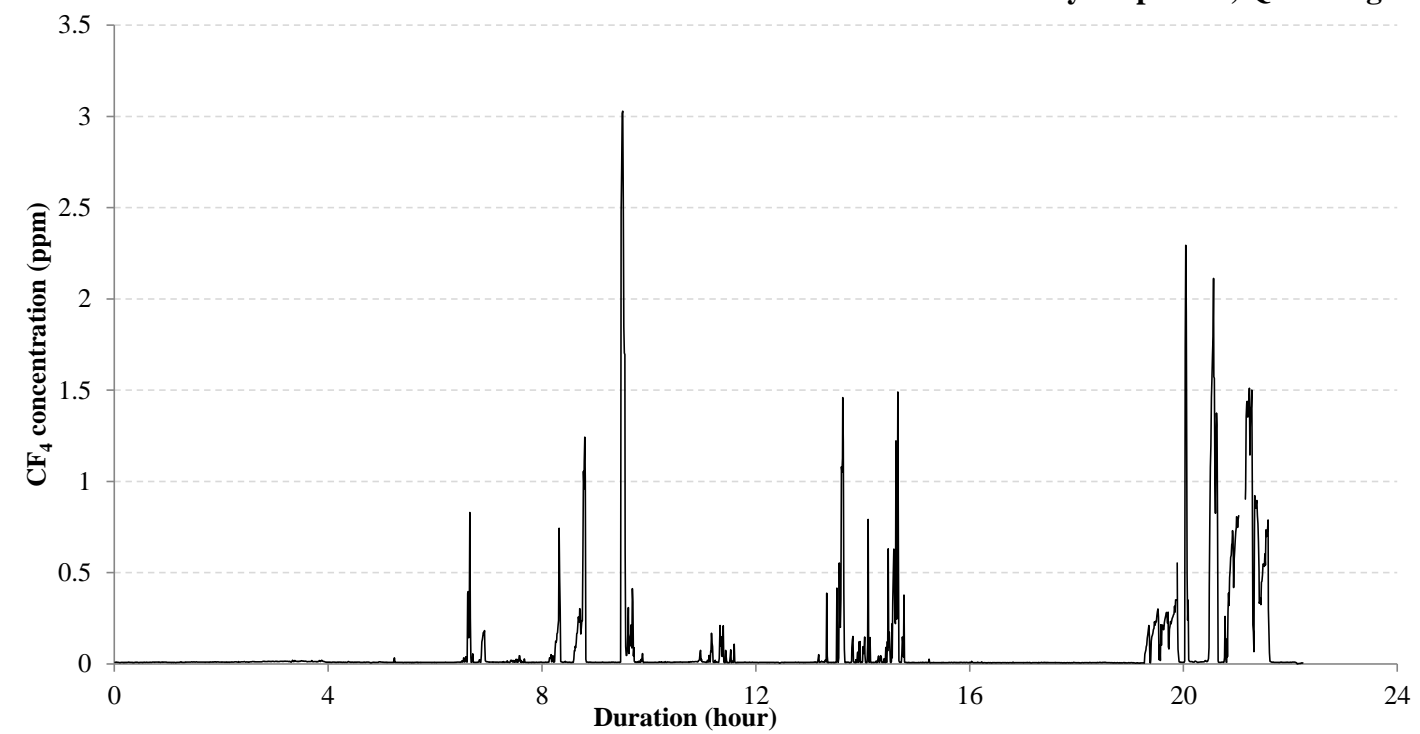

Figure 3: $\mathrm{CF}_{4}$ concentration of Dy-Fe potline $(1$ cell) in Qiandong during regular production

The La potline in Qiandong included 6 pots and monitoring was conducted over 36 hours (Figure 4). Similar to the other observations, a number of anode effect events were also captured and the maximum concentration of $\mathrm{CF}_{4}$ was $0.194 \mathrm{ppm}$. An estimated $61 \%$ of emissions were attributed to AEs, with $39 \%$ attributed to NAE emissions. The overall $\mathrm{CF}_{4}$ emission factor was $36.16 \mathrm{~g} / \mathrm{t}$-RE and the $\mathrm{CO}_{2}$-equivalent emission factor was $239.74 \mathrm{~kg} \mathrm{CO}_{2}$-e/t-RE. 


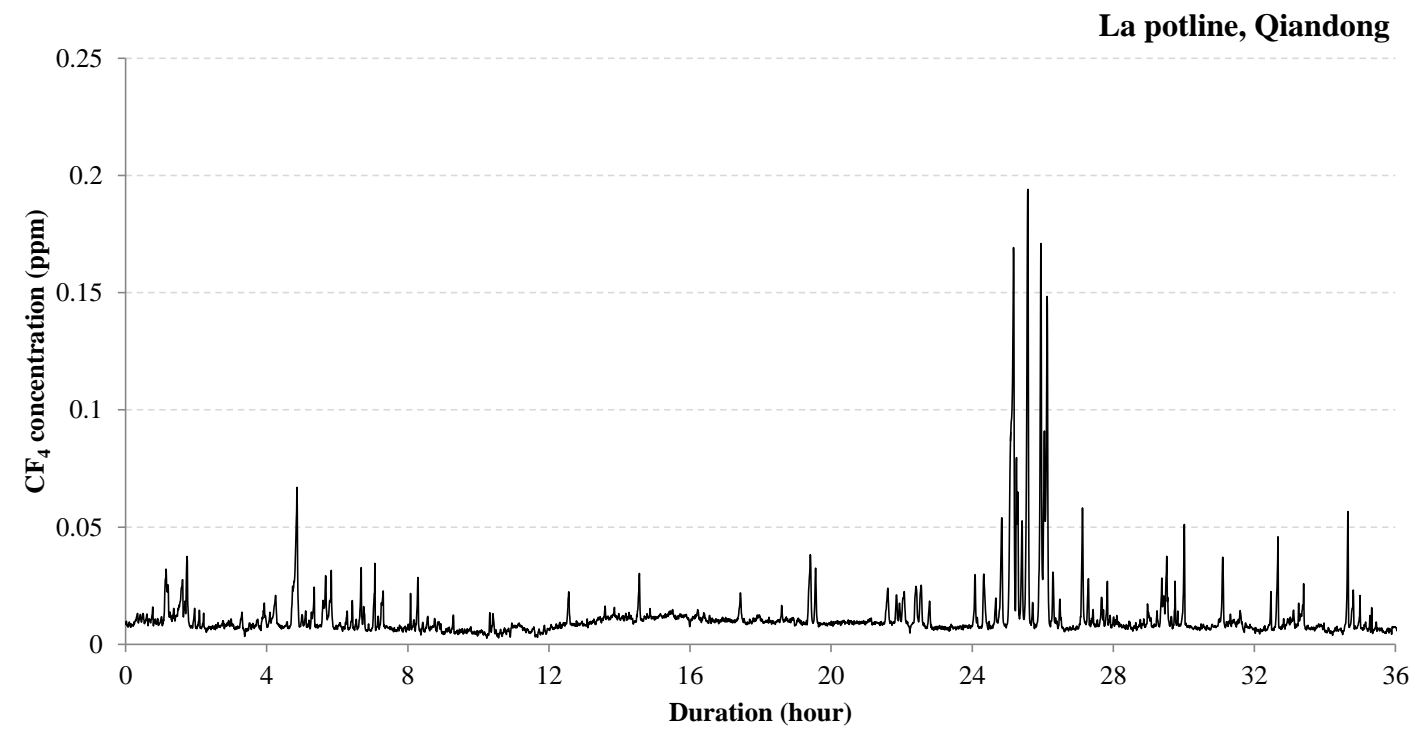

Figure 4: $\mathrm{CF}_{4}$ concentration of La potline (6 cells) in Qiandong during regular production

At the Ionic Rare Earth Centre, the Pr-Nd potline which had 6 pots was monitored over 36 hours (Figure 5). Anode effect events were not so frequent compared to other potlines, as shown by fewer peak emission events. However, when they did occur, peak emissions were greater than that in the other Pr-Nd potline at Qiandong, with a maximum $\mathrm{CF}_{4}$ concentration of $0.728 \mathrm{ppm}$. In terms of total $\mathrm{CF}_{4}$, an estimated $53 \%$ were attributed to $\mathrm{AEs}, 47 \%$ to NAE emissions. $\mathrm{A} \mathrm{CF}_{4}$ emission factor of $33.96 \mathrm{~g} / \mathrm{t}-\mathrm{RE}$ was determined for this potline, equal to $225.15 \mathrm{~kg} \mathrm{CO}_{2}$-e/t-RE.

Pr-Nd potline, Ionic Rare Earth Centre

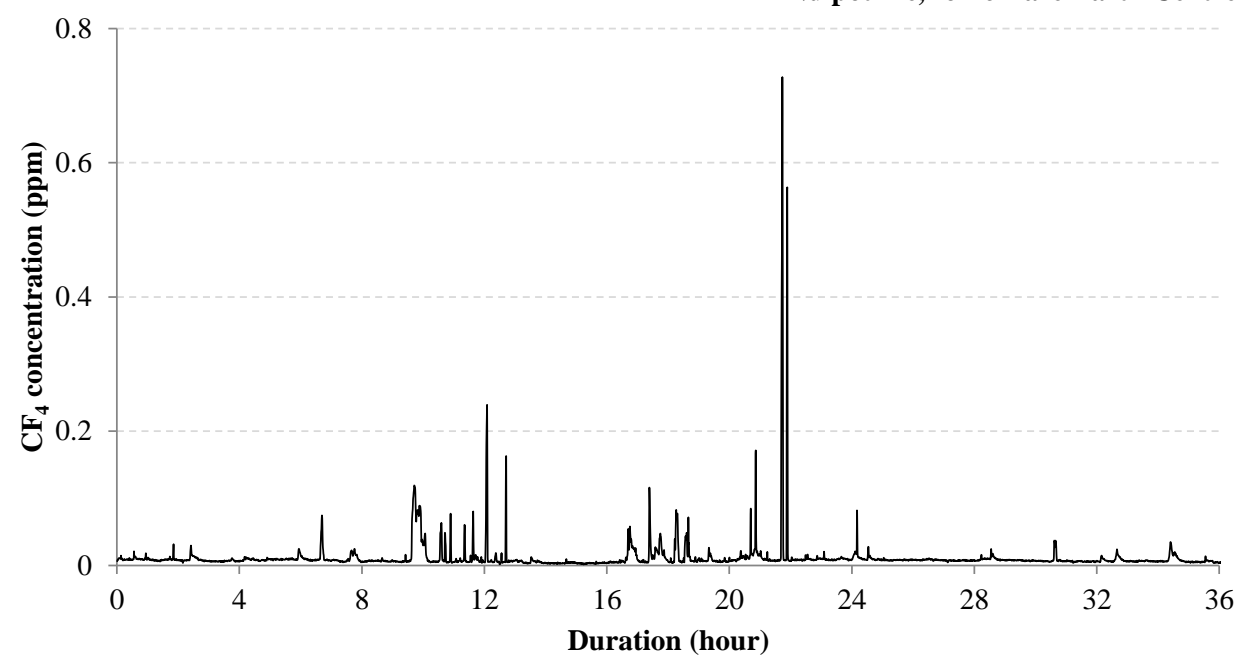

Figure 5: $\mathrm{CF}_{4}$ concentration of Pr-Nd potline (8 pots) in Ionic Rare Earth Centre during regular production

Originally, plans were made to examine the effect of line current and different cell technologies on PFC emissions, by measuring PFC emissions from Pr-Nd potlines at three companies for $>=24$ hours, each with varying line current (Table 1). However at Jiangxi South, continuous monitoring was interrupted after only 8 hours when the company had to change the settings of the potline and the production equipment. Furthermore, no AE events were observed 
during the 8 hours of monitoring and therefore emission factors based on this data would likely be an under-estimate of actual emission intensities. Therefore, monitoring data and a corresponding emission factor for Jiangxi South's Pr-Nd potline have not been included here. Unfortunately, this meant that emission factors for a higher-amperage cell technology (>10 kA) could not be estimated.

Table 2 summarizes the emission factors $\mathrm{CF}_{4}$ for all four potlines (excluding Jiangxi South), alongside relevant technical process data, determined gas collection efficiencies and parameters relating to the gas sampling. As explained previously, for the same rare earth metal the magnitude of PFC emissions can vary considerably with the operating line current. Therefore, it is crucial to clearly highlight the current while calculating the emission factor. Moreover, it is crucial to take into account the gas collection efficiency at each company when determining emission factors to ensure fugitive gas emissions that escape the exhaust gas collection system are accounted for.

From $\mathrm{SF}_{6}$ tracer studies, the gas collection efficiency at both Qiandong and Ionic Rare Earth Center was found to be approximately 57\%. At Jiangxi South, this was around 53\%, being slightly lower. Therefore, significant improvement in gas collection efficiency cannot be achieved by only small changes to potroom conditions with no fundamental innovation of the current electrolysis technology.

From Table 2, it is clear that estimated $\mathrm{CF}_{4}$ emission factors vary significantly from one $\mathrm{RE}$ metal/alloy to another. For production of Pr-Nd alloy, $\mathrm{CF}_{4}$ emission factors also varied between different companies, with $\mathrm{CF}_{4}$ emissions at Ionic Rare Earth Center being roughly $80 \%$ that at Qiandong. It is possible that this is due to fluctuation of gas collection efficiency over time at each company, due to smelter workers' frequent adjustments of the gas collection hoods during monitoring (each company had differing gas collection systems). Furthermore, this might also be attributed to differences in process operating conditions (temperature, voltage, etc, as might be suggested by differences in net anode carbon consumption in Table 2).

Also summarized in Table 2 are the contribution of AEs (peak emission events) to total $\mathrm{CF}_{4}$, ranging from $53 \%$ to $91 \%$ over the four potlines with valid data. These highlight that PFCs can also be generated outside of an anode effect condition. As a point of discussion, since no anode effects were detected during Jiangxi South monitoring (data not shown here), AE-related emissions could not be estimated and therefore all measured $\mathrm{CF}_{4}$ was attributed to NAE emissions. Again, the 8 hours of monitoring at this production line was deemed insufficient to provide a meaningful representation of emissions performance at this company and hence emission factors were not calculated. 
Table 2: The emission factor of $\mathrm{CF}_{4}$ for different production lines based on on-site monitoring

\begin{tabular}{|c|c|c|c|c|}
\hline Company & & Qiandong & & Ionic Rare Earth Center \\
\hline Potline & $\operatorname{Pr}-N d$ & $D y-F e$ & $L a$ & $\operatorname{Pr}-N d$ \\
\hline $\begin{array}{c}\text { Gas flow rate at the } \\
\text { sampling point }\left(\mathrm{Nm}^{3} / \mathrm{h}\right)\end{array}$ & 12,000 & 1,340 & 17,066 & 18,327 \\
\hline $\begin{array}{l}\text { Diameter of the gas stack } \\
\text { (m) }\end{array}$ & 1.2 & 0.2 & 0.8 & 0.6 \\
\hline $\begin{array}{l}\text { Production of RE metal } \\
\text { (t/d) }\end{array}$ & 2.173 & 0.150 & 0.930 & 0.965 \\
\hline $\begin{array}{l}\text { Net anode carbon } \\
\text { consumption } \\
(\mathrm{kg}-\mathrm{C} / \mathrm{t}-\mathrm{RE})\end{array}$ & 136.5 & 166.6 & 144.3 & 160 \\
\hline $\begin{array}{c}\text { Gas collection efficiency } \\
(\%)\end{array}$ & 57.97 & 57.97 & 57.97 & 56.22 \\
\hline $\begin{array}{l}\text { Emission factor of } \mathrm{CF}_{4} \\
\text { (g/t-RE) }\end{array}$ & 26.66 & 109.43 & 36.16 & 33.96 \\
\hline $\begin{array}{c}\% \mathrm{CF}_{4} \text { emissions related } \\
\text { to AEs }\end{array}$ & $75 \%$ & $91 \%$ & $61 \%$ & $53 \%$ \\
\hline
\end{tabular}

3

\subsection{Estimation of $\mathrm{C}_{2} \mathrm{~F}_{6}$ and $\mathrm{C}_{3} \mathrm{~F}_{8}$ emission factors from Time-Integrated}

\section{Sampling \& Lab Analysis}

Analysis of time-integrated canister samples in the laboratory provided significantly higher sensitivities in detecting greenhouse gases. Analysis results confirmed that addition to $\mathrm{CF}_{4}, \mathrm{C}_{2} \mathrm{~F}_{6}$ and $\mathrm{C}_{3} \mathrm{~F}_{8}$, enhanced concentrations (concentration of exhaust gas minus background samples) of two other PFCs were observed in part of the samples, namely $c-\mathrm{C}_{4} \mathrm{~F}_{8}$ and $\mathrm{C}_{4} \mathrm{~F}_{10}$. However, it was found that for all four potlines (Jiangxi South excluded), the ratio of the enhanced concentrations of $\mathrm{c}-\mathrm{C}_{4} \mathrm{~F}_{8}$ and $\mathrm{C}_{4} \mathrm{~F}_{10}$ to $\mathrm{CF}_{4}$ were $<0.05 \%$. This ratio was so low that no further emission factor estimation was conducted for these gases.

Concentration ratios of $\mathrm{C}_{2} \mathrm{~F}_{6}$ and $\mathrm{C}_{3} \mathrm{~F}_{8}$ to $\mathrm{CF}_{4}$ are presented in Table 3 . It is clear that, in all potlines regardless of line current and potroom conditions, $\mathrm{CF}_{4}$ is consistently the dominant $\mathrm{PFC}$ gas emitted, taking up more than $90 \%$ of total PFCs detected. Furthermore, while $\mathrm{C}_{3} \mathrm{~F}_{8}$ cannot be ignored (compared to $\mathrm{c}-\mathrm{C}_{4} \mathrm{~F}_{8}$ and $\mathrm{C}_{4} \mathrm{~F}_{10}$ ), it contributes to less than $1 \%$ of total PFCs and is at the lowest concentration amongst the three main PFC gases of interest.

By referring to the obtained $\mathrm{CF}_{4}$ emission factors from FTIR measurements (Table 2) and the corresponding concentration ratios determined from the lab analysis of time-integrated samples (Table 3), emission factors of $\mathrm{C}_{2} \mathrm{~F}_{6}$ and $\mathrm{C}_{3} \mathrm{~F}_{8}$ from each potline then can be calculated by 


\begin{tabular}{|c|c|c|c|c|c|}
\hline \multicolumn{2}{|c|}{ Company } & \multicolumn{3}{|c|}{ Qiandong } & \multirow{2}{*}{$\begin{array}{c}\text { Ionic Rare Earth Center } \\
P r-N d\end{array}$} \\
\hline & & $P r-N d$ & $D y-F e$ & $L a$ & \\
\hline No. & & 15 & 1 & 6 & 6 \\
\hline Line cu & $(\mathrm{kA})$ & 5 & 5 & 5 & 6 \\
\hline \multirow{2}{*}{$\begin{array}{l}\text { Conc. } \\
\text { Ratio }\end{array}$} & $\begin{array}{c}\mathrm{D}_{\mathrm{C} 2 \mathrm{~F} 6} / \\
\mathrm{D}_{\mathrm{CF} 4}\end{array}$ & 0.0714 & 0.06384 & 0.0046 & 0.2033 \\
\hline & $\begin{array}{c}\mathrm{D}_{\mathrm{C} 3 \mathrm{~F} 8} / \\
\mathrm{D}_{\mathrm{CF} 4}\end{array}$ & 0.00355 & 0.00015 & 0.0013 & 0.0037 \\
\hline \multirow{2}{*}{$\begin{array}{c}\text { EF Mass } \\
\text { Ratio }\end{array}$} & $\begin{array}{c}\mathrm{EF}_{\mathrm{C} 2 \mathrm{~F} 6} / \\
\mathrm{EF}_{\mathrm{CF} 4}\end{array}$ & 0.1119 & 0.1001 & 0.0072 & 0.31882 \\
\hline & $\begin{array}{c}\mathrm{EF}_{\mathrm{C} 3 \mathrm{~F} 8} / \\
\mathrm{EF}_{\mathrm{CF} 4}\end{array}$ & 0.0076 & 0.00031 & 0.0028 & 0.0079 \\
\hline \multicolumn{2}{|c|}{$\mathrm{EF}_{\mathrm{CF} 4}(\mathrm{~g} / \mathrm{t}-\mathrm{RE})$} & 26.66 & 109.43 & 36.16 & 33.96 \\
\hline \multicolumn{2}{|c|}{$\mathrm{EF}_{\mathrm{C} 2 \mathrm{~F} 6}(\mathrm{~g} / \mathrm{t}-\mathrm{RE})$} & 2.98 & 10.95 & 0.26 & 10.83 \\
\hline \multicolumn{2}{|c|}{$\mathrm{EF}_{\mathrm{C} 3 \mathrm{~F} 8}(\mathrm{~g} / \mathrm{t}-\mathrm{RE})$} & 0.19 & 0.03 & 0.10 & 0.27 \\
\hline
\end{tabular}

Eq. 11 and Eq. 12. Interestingly, the mass ratio of $\mathrm{EF}_{\mathrm{C} 2 \mathrm{~F} 6} / \mathrm{EF}_{\mathrm{CF} 4}$ in two Qiandong potlines (Pr-Nd and $\mathrm{Dy}-\mathrm{Fe}$ ) is similar to the $10 \%$ ratio typically found in aluminium electrolysis (IAI, 2017), while the other two RE potlines differed as is the case for different technology cells in aluminium (IAI, 2017).

As presented in Table 3, Qiandong Dy-Fe alloy and La potlines had $\mathrm{C}_{2} \mathrm{~F}_{6}$ emission factors of $10.95 \mathrm{~g} / \mathrm{t}-\mathrm{RE}$ and $0.26 \mathrm{~g} / \mathrm{t}-\mathrm{RE}$, respectively, and $\mathrm{C}_{3} \mathrm{~F}_{8}$ emission factors of $0.03 \mathrm{~g} / \mathrm{t}-\mathrm{RE}$ and 0.10 $\mathrm{g} / \mathrm{t}-\mathrm{RE}$, respectively. Foreseeably, the emission factors of both $\mathrm{C}_{2} \mathrm{~F}_{6}$ and $\mathrm{C}_{3} \mathrm{~F}_{8}$ for Pr-Nd alloy production lines in Qiandong differ from that in the Ionic Rare Earth Center. Specifically, in Qiandong the $\mathrm{C}_{3} \mathrm{~F}_{8}$ emission factor is $0.19 \mathrm{~g} / \mathrm{t}-\mathrm{RE}$, almost $30 \%$ lower than that in Ionic Rare Earth Center; this is not surprising, given that $\mathrm{CF}_{4}$ emission factors were also $\sim 20 \%$ lower at Qiandong. Interestingly, for $\mathrm{C}_{2} \mathrm{~F}_{6}$, the outcome from Qiandong is $2.98 \mathrm{~g} / \mathrm{t}-\mathrm{RE}$, around $70 \%$ lower than that from Ionic Rare Earth Center, given the ratio of $\mathrm{C}_{2} \mathrm{~F}_{6}$ to $\mathrm{CF}_{4}$ at Ionic Rare Earth Centre is almost 3 times higher.

Table 3: The estimated emission factors (EF) for $C_{2} F_{6}$ and $C_{3} F_{8}$
17

\subsection{Uncertainty Analysis}

Due to uncontrollable factors in monitoring, the estimated emission factors inevitably have statistically errors which should not be ignored. From Eq. 9, we can infer that the uncertainty pertaining to $\mathrm{CF}_{4}$ emission factor mainly comes from three aspects, which are the measurement of the emission concentration, of the gas flow rate and of the gas collection efficiency. Suppose the relative standard deviations in these three aspects are $\varepsilon_{\mathrm{CF} 4}, \varepsilon_{\mathrm{F}}, \varepsilon_{\mathrm{Ecol}}$, the relative standard error $\left(\varepsilon_{\mathrm{R}}\right)$ 
is calculated as below:

$$
\varepsilon_{\mathrm{R}}=\left(\varepsilon_{\mathrm{CF} 4}^{2}+\varepsilon_{\mathrm{F}}^{2}+\varepsilon_{\mathrm{Ecol}}^{2}\right)^{1 / 2} \quad(\text { Eq. 13) }
$$

$$
\mathrm{U}_{\mathrm{CF} 4}=\mathrm{EF}_{\mathrm{CF} 4} \times \mathcal{E}_{\mathrm{R}}
$$

and the results are listed in Table 4.

It is necessary to keep information in these aspects as reference for further estimation of global $\mathrm{CO}_{2}$ equivalent emission from rare earth metal electrolysis.

Table 4: $\mathrm{CO}_{2}$ equivalent emission factors and uncertainty of PFC emissions

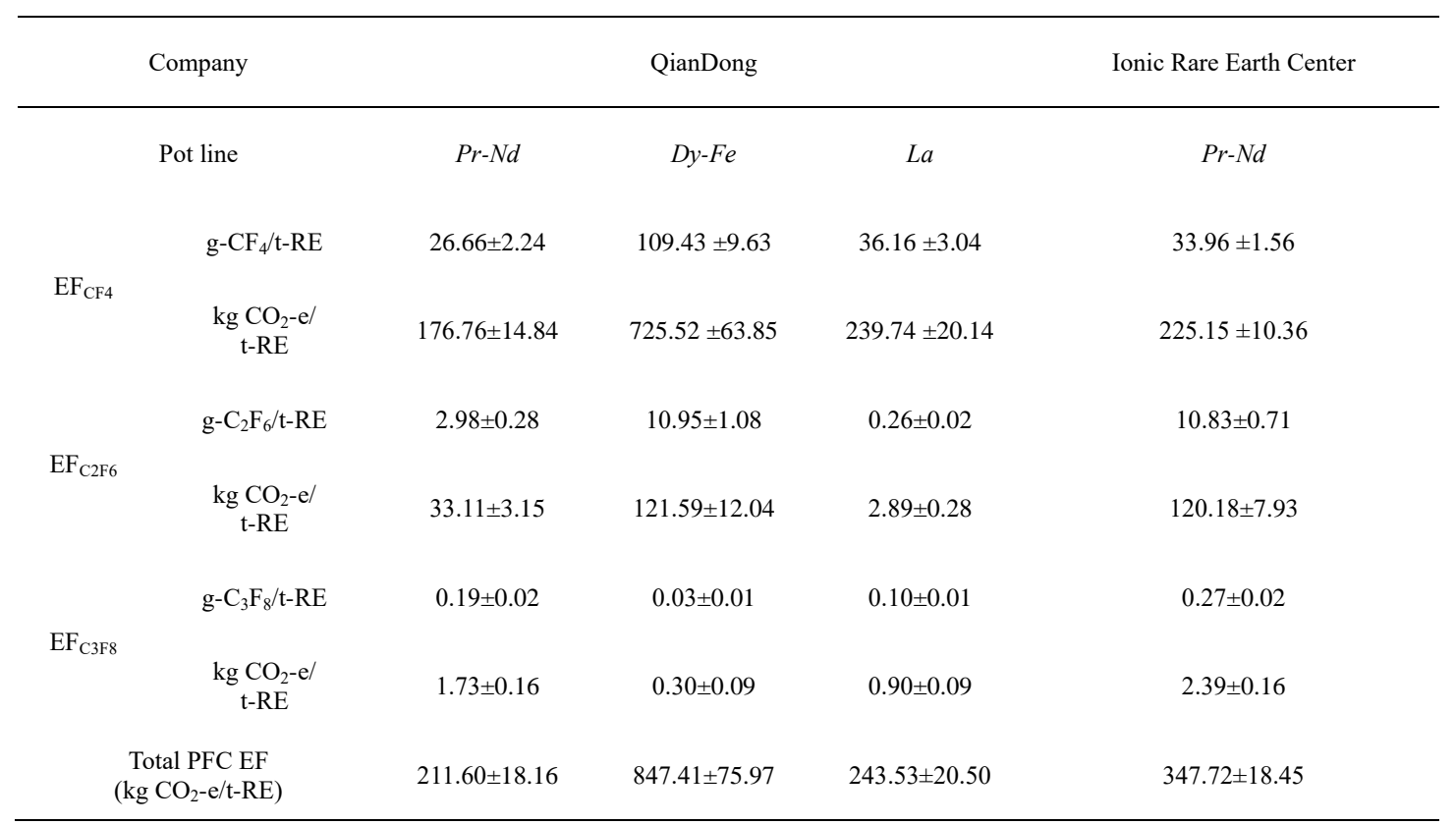

\subsection{Discussion on PFC Emission Factors}

Using GWPs for the three main PFCs of interest $-\mathrm{CF}_{4}, \mathrm{C}_{2} \mathrm{~F}_{6}$ and $\mathrm{C}_{3} \mathrm{~F}_{8}-$ a converted $\mathrm{CO}_{2}$-equivalent emission factor for total PFCs can be estimated for the four potlines (Table 4). All emission factors except that for $D y-F e$ alloy production are lower than $350 \mathrm{~kg} \mathrm{CO}_{2}$-e/t-RE, an equivalent target level for the Chinese aluminium industry by 2020. This highlights the importance of focusing on reducing PFC emissions from $\mathrm{Dy}$-Fe alloy production, which had the highest emissions intensity from this study and the 2014 study (Zhang et al., 2018).

It is also pertinent to compare the rare earth PFC emission factors determined in this work with those from the aluminium industry. When compared to Chinese aluminium industry's 2020 target of $350 \mathrm{~kg} \mathrm{CO}$-e/t-Al and the global aluminium industry's 2016 overall PFC emission intensity of $640 \mathrm{~kg} \mathrm{CO}_{2}$-e/t-Al (estimated global emission factor from the 2016 IAI Anode Effect Survey (2017), albeit using GWPs from the IPCC Fourth Assessment Report), this implies that in most situations PFC emissions intensity (on a mass basis) from rare earth metal electrolysis is on a lower or similar order of magnitude to emissions from aluminium electrolysis. Note that for fundamental understanding of PFC generation, the molar mass of rare earth metals (e.g. Nd at 144 $\mathrm{g} / \mathrm{mol})$ is roughly 5 times greater than that of aluminium $(27 \mathrm{~g} / \mathrm{mol})$; therefore, PFC emission 
intensities for rare earth metals are 5 times greater on a mole-basis than for aluminium. For the practical purpose of emissions accounting from industry however, it is more appropriate to compare emission intensities by mass.

In a general sense, the rare earth metal production settings such as cell size, voltage and current have an evident impact upon the PFC emissions. For instance, high cell voltage operation (e.g. on Dy-Fe cells) can result in more fluoride participating in the electrolysis reaction, thus generating more anode effects which results in more frequent spikes in PFC emission. Therefore, emission factors determined for each of the four potlines should be attached with information that describes these settings.

Moreover, it is worth emphasising again that the high emission factor for Dy-Fe alloy has been based upon observed data from only one single pot. Inevitably it incurs the risk of uncertainty and may be less representative for $D y-F e$ alloy production. Nonetheless, we retained this data so as to maintain coverage over production multiple rare earth metals. In any case, this salient value presents us with a necessity to explore the underlying causes that lead to greater emissions and formulate effective solutions to reduce them in $D y-F e$ alloy production.

The comparison of AE-related emissions (ranging from 53\% to $91 \%$ ) vs. NAE-related emissions is also of particular interest since (1) it highlights that PFC emissions can be generated on industrial cells outside of an anode effect and (2) similar NAE-emissions have also been found in industrial aluminium electrolysis (Wong et al., 2015) and are now known in that industry to be difficult to detect, both by operators and control systems. In contrast, AE-related emissions are often correlated with high-voltage events on cells, which can be used to detect, mitigate and account for AE-related emissions. Applied to the rare earths industry, this would mean NAE-related PFC emissions will be difficult to detect and account for (without sophisticated instrumentation) and more importantly to mitigate.

Finally, the current study provides much greater coverage than previous studies in providing PFC emission factors for multiple gases $\left(\mathrm{CF}_{4}, \mathrm{C}_{2} \mathrm{~F}_{6}, \mathrm{C}_{3} \mathrm{~F}_{8}\right)$ from three of the most common rare earth metals produced by electrolysis. However, given the lack of valid data from Jiangxi South, no conclusive observations can be made as to the impact of line-current on emissions intensity. This would be a good area of focus for further studies by the industry into PFCs from rare earths.

\section{Conclusions}

Through on-site FTIR monitoring and lab analysis of time-integrated samples, it was confirmed that in addition to $\mathrm{CF}_{4}$ there are four other $\mathrm{PFC}$ emissions in the exhaust gas from industrial rare earth electrolysis, namely: $\mathrm{C}_{2} \mathrm{~F}_{6}, \mathrm{C}_{3} \mathrm{~F}_{8}, c-\mathrm{C}_{4} \mathrm{~F}_{8}$ and $\mathrm{C}_{4} \mathrm{~F}_{10}$. While these four components could not be measured directly by the FTIR, time-integrated samples obtained during on-site monitoring were analysed in the lab using a custom-built 'Medusa' GC-MS system. The result shows that in all the four examined potlines ( $\mathrm{Pr}-\mathrm{Nd}$, Dy-Fe and La production at Qiandong and $\mathrm{Pr}-\mathrm{Nd}$ production at the Ionic Rare Earth Center), $\mathrm{CF}_{4}$ is absolutely the primary PFC component, accounting for roughly $90 \%$ of PFC gases by mass. The concentration ratio of both $\mathrm{C}_{2} \mathrm{~F}_{6}$ and $\mathrm{C}_{3} \mathrm{~F}_{8}$ to $\mathrm{CF}_{4}$ differs somewhat across these four pot lines - for $\mathrm{C}_{2} \mathrm{~F}_{6}$ it is roughly $10 \% \mathrm{wt}$ (similar to that in industrial aluminium electrolysis) and for $\mathrm{C}_{3} \mathrm{~F}_{8}$ the ratio is less than $1 \% \mathrm{wt}$. As the ratios of the enhanced concentrations of $\mathrm{c}-\mathrm{C}_{4} \mathrm{~F}_{8}$ and $\mathrm{C}_{4} \mathrm{~F}_{10}$ to $\mathrm{CF}_{4}$ across four potlines are both 
less than $0.05 \%$, calculation of their emission factors was not conducted in this research.

Emissions vary from one rare earth metal to another and from company to another for the same metal. In general, PFC emission intensities for most rare earth metals are of a lower level of magnitude (by-mass) compared to industrial aluminium electrolysis, with the exception of Dy-Fe electrolysis. Factors behind the variation in emissions intensity include not only electrical line current, but also cell design, operating conditions and process technology employed - as shown by reductions in Pr-Nd emissions intensity at Qiandong smelter after improvements to oxide feeding technology (Zhang et al, 2018 vs. this work) - and as highlighted by differences in operating voltage, fluoride consumption and anode carbon consumption. Unfortunately, comparison of emission intensities across low vs. high-amperage cell technologies was inconclusive, given the lack of valid data at Jiangxi South smelter.

\section{Acknowledgements}

The authors of this work acknowledge all parties involved in the measurement team and the three rare earth companies that participated in the research: Qiandong Rare Earths Group Co. Ltd, National Engineering Research Center for Ionic Rare Earth and Jiangxi South Rare Earth High Tech. Co. Ltd. We would also like to give our special thanks for the funding support from the following institutions: (1) An Emission-Transport-Exposure Model Based Study on the Evaluation of the Environmental Impact of Carbon Market (Grant No. 71673107) and a fluorinated greenhouse emission study (Grant No. 41575114), both supported by the National Natural Science Foundation of China; (2) The Recruitment Program of Global Experts (Youth Group) of China (Grant No. D1218006); and (3) Technology Innovation Foundation of Hubei Province (Grant No. 2017ADC073).

\section{References}

Chase R, Gibson R and Marks J. (2005) PFC emissions performance for the global primary aluminum industry. In: Kvande H (ed) Light Metals. 279-282.

Fraser P., Steele P., Cooksey M. (2013) PFC and Carbon Dioxide Emissions from an Australian Aluminium Smelter Using Time-Integrated Stack Sampling and GC-MS, GC-FID Analysis. In: Sadler B.A. (eds) Light Metals 2013. The Minerals, Metals \& Materials Series. Springer, Cham.

https://doi.org/10.1007/978-3-319-65136-1_148

International Aluminium Institute (IAI), World Aluminium-Alumina Production (2014), Available from: http://www.world-aluminium.org/statistics/alumina-production/.

International Aluminium Institute (IAI), Results of the 2016 Anode Effect Survey: Report on the Aluminium Industry's Global Perfluorocarbon Gases Emissions, Available from:

http://www.world-aluminium.org/media/filer public/2017/07/26/2016 anode effect survey result 2017.pdf IPCC. (2006) 2006 Ipcc Guidelines for National Greenhouse Gas Inventories. Japan: IGES, 2006. IPCC. (2006) 2006 IPCC Guidelines for National Greenhouse Gas Inventories: Japan: IGES, 2006.List of Contributing Authors, Available from: https://www.ipcc-nggip.iges.or.jp/public/2006gl/pdf/0_Overview/V0_3_Contributor.pdf 
IPCC. (2013) Climate Change 2013: The Physical Science Basis. Contribution of Working Group I to the Fifth Assessment Report of the Intergovernmental Panel on Climate Change. Cambridge, United Kingdom and New York,USA: Cambridge University Press.

Kim, J., et al. (2014), Quantifying aluminum and semiconductor industry perfluorocarbon emissions from atmospheric measurements, Geophys. Res. Lett., 41, 4787-4794, doi:10.1002/ 2014GL059783.

Kjos, O.S., Solheim, A., Aarhaug, T. Osen, K.S., Martinez, A.M., Sommerseth, C., Gudbrandsen H., Støre, A. \& Gaertner, H. (2018) PFC evolution characteristics during aluminium and rare earth electrolysis, In: TMS Light Metals, paper to be presented at Phoenix, Arizona, March 11-15, 2018.

Liu W. (2008) The development of China sintered ND-Fe-B magnets industry and its manufacture techniques. Metal World 15(6): 38-41.

Myhre, G., D. Shindell, F.-M. Bréon, W. Collins, J. Fuglestvedt, J. Huang, D. Koch, J.-F. Lamarque, D. Lee, B. Mendoza, T. Nakajima, A. Robock, G. Stephens, T. Takemura and H. Zhang, 2013: Anthropogenic and Natural Radiative Forc- ing. In: Climate Change 2013: The Physical Science Basis. Contribution of Working Group I to the Fifth Assessment Report of the Intergovernmental Panel on Climate Change [Stocker, T.F., D. Qin, G.-K. Plattner, M. Tignor, S.K. Allen, J. Boschung, A. Nauels, Y. Xia, V. Bex and P.M. Midgley (eds.)]. Cambridge University Press, Cambridge, United Kingdom and New York, NY, USA. Available from: https://www.ipcc.ch/pdf/assessment-report/ar5/wg1/WG1AR5 Chapter08 FINAL.pdf

Prinn, R. G., Weiss, R. F., Arduini, J., Arnold, T., DeWitt, H. L., Fraser, P. J., Ganesan, A. L., Gasore, J., Harth, C. M., Hermansen, O., Kim, J., Krummel, P. B., Li, S., Loh, Z. M., Lunder, C. R., Maione, M., Manning, A. J., Miller, B. R., Mitrevski, B., Mühle, J., O'Doherty, S., Park, S., Reimann, S., Rigby, M., Saito, T., Salameh, P. K., Schmidt, R., Simmonds, P. G., Steele, L. P., Vollmer, M. K., Wang, R. H., Yao, B., Yokouchi, Y., Young, D., and Zhou, L.:(2018) History of Chemically and Radiatively Important Atmospheric Gases from the Advanced Global Atmospheric Gases Experiment (AGAGE), Earth Syst. Sci. Data Discuss., https://doi.org/10.5194/essd-2017-134, in review

Ren LK, She CJ and Wei XJ. (2001) Analysis of anodic gases in neodymium electrolysis. Chinese Journal of Nonferrous Metals.

Rhoderick G, Chu P, Dolin E, et al. (2001) Development of perfluorocarbon (PFC) primary standards for monitoring of emissions from aluminum production. Fresenius Journal of Analytical Chemistry 370(7): 828-833.

Tabereaux AT. (1994) Anode effects, PFCs, global warming, and the aluminum industry. JOM 46(11): 30-34.

U.S. Geological Survey, Mineral Commodity Summaries-Rare Earths (Reston, VA: U.S. Geological Survey, 2014), pp. 128-129.

Vogel, H., Flerus, B., Stoffner, F. \& Friedrich, B. (2017a) Reducing Greenhouse Gas Emission from the Neodymium Oxide Electrolysis. Part I: Analysis of the Anodic Gas Formation. Journal of Sustainable Metallurgy 3(1): 99-107.

Vogel, H. \& Friedrich, B. (2015) Development and Research Trends of the Neodymium Electrolysis - A Literature Review. In: 8th European Metallurgical Conference (EMC), Dusseldorf, Germany.

Vogel H and Friedrich B. (2017b) Reducing Greenhouse Gas Emission from the Neodymium Oxide Electrolysis. Part II: Basics of a Process Control Avoiding PFC Emission. International Journal of Nonferrous Metallurgy 06(3): 27-46.

Wen H, Kuang G and Mao J. (2012) 25 KA rare earth electrolytic cell for fluoride molten salt system Beijing: China's State Intellectual Property Office, 1-6.

Wong DS, Fraser P, Lavoie P, et al. (2015) PFC Emissions from Detected Versus Nondetected Anode Effects in the Aluminum Industry. JOM 67(2): 342-353. 
Wen, H., Kuang, G. \& Mao, J. (2012) 25 KA rare earth electrolytic cell for fluoride molten salt system. In: ed. China's State Intellectual Property Office, pp. 1-6. China.

3 Gen Zhang, Bo Yao, Martin K. Vollmer, Stephen A. Montzka, Jens Mühle, Ray F. Weiss, Simon O'Doherty, Yi Li, Shuangxi Fang, Stefan Reimann (2017). Ambient mixing ratios of atmospheric halogenated compounds at five background stations in China. Atmospheric Environment 160: 55-69. http://dx.doi.org/10.1016/j.atmosenv.2017.04.017.

7 Zhang, L., Wang, X., \& Gong, B. (2018). Perfluorocarbon emissions from electrolytic reduction of rare earth 8 metals in fluoride/oxide system. Atmospheric Pollution Research., 9(1): 61-65.

9 Zhao CF, Zhang SC, Huang X, et al. (2008) Study of PFC emission in aluminum industry. Light Metals 